\title{
LUTE MUSIC IN THE AREA OF CONTEMPORARY SLOVAKIA IN THE PERIOD OF RENAISSANCE JEAN BAPTISTA BESARD - THESAURUS HARMONICUS
}

The article analyses the issue of occurrence of lute music, its repertoire, players, and composers connected with the area of Slovakia in the age of humanism.

\section{Introducion}

Lute played an important role in the history of the European musical culture of the $16^{\text {th }}$ and $17^{\text {th }}$ centuries. It influenced some processes of musical history to a considerable extent, e.g. stabilization of tonality, development of variety principle, formation of suite and development of note writing. In our musicology literature there are not many works to be found that would deal in detail with the occurrence of lute music in Slovakia or individual relics related to this kind of music. Some mentions about lute music in Slovakia can be found in compilatory /synthetical works of František Fagiba [1], Richard Rybarič [2], Ladislav Kačic [3]. Antonín Hořejš[4] and Marta Hulková [5] make analyses of lute relics in the area of Spiš region. Ingeborg Šišková [6] brings scientific elaboration of the transcription of the lute tablature in Slovakia. Péter Király [7] ranks among the experts abroad dealing with study of lute play in the area of the former Hungary. Foreign lexicons also cover the issue of lute play.

\section{Lute music in the area of contemporary slovakia in the period or renaissance}

During the period of Renaissance in the area of the presentday Slovakia significant economic, political and cultural changes were happening and they resulted in better conditions for the development of musical culture and the occurrence of lute music accordingly. The evidence of this are also some references about activities of some lute players of European dimension like Hans Newsidler or Bálint Bakfark [8]. The highest level of musical life was reached together with Bratislava in towns of Eastern Slovakia - the extent of music collections of Levoča and Bardejov confirm this.

[5] In literature we can find information about an early existence of music for this instrument from the $1^{\text {st }}$ half of the $16^{\text {th }}$ century. Several significant people - lute players of that time - are related to Slovakia. Bratislava is stated as a birthplace of the Newsidler brothers, Hans (1508-1563) and Melichor (1507-1590), German lute players acting in Norimberg. In 1530 Hans Newsidler moved from Bratislava to Norimberg where he published a few tablature books for six-course lute. Despite his numerous stays in Vienna during his journeys across Europe, there were no traces left of him in Slovakia. We can assume that he gained basic musical education in Bratislava, which can be proved by the existence of lute playing in this town in that period. A Hungarian poet, Sebestyén Tinódi (1505-1556) was another lute player, a creator of a historical song and the author of the collection Cronica In 1544 he stayed in Trnava as well as in other parts of Slovakia. Tinódi ranked among the musicians (lute players) wandering around Slovakia and with his singing accompanied by lute revolting against the Turks [1]. Some connections between Slovakia and Bálint Bakfark (1507-1576),

one of the most important lute players in the $16^{\text {th }}$ century, have been made in literature. He was active in the noble courts of Europe. František Zagiba [1] traces back his stay in our area, his visit to Trenčin and possibly giving concerts in 1566. Lives of these three personalities of lute music are closely connected with the period when in Slovakia - in contrast to the past - there were many major political, industrial and cultural changes With the oncoming reformation the gregorian chant ceased to be the object of interest and attention was shifted to spiritual songs and secular music. These tendencies were best demonstrated in three regions - Bratislava in the west, Kremnica and Banská Bystrica in central Slovakia and Spiš region and Bardejov in the east. In the inventory of an evangelical church in Bratislava there are two compositions from 1651 where lutes are mentioned in consort music. [9] On the basis of this we can come to the conclusion that lute music existed in this town. In towns of eastern Slovakia the musical life reached the highest level, together with Bratislava. The evidence of this is the scale of Levoča's and Bardejov`s collections of music of $16^{\text {th }}$

\footnotetext{
* Michal Hottmar

Department of Musicology, Faculty of Philosophy, Comenius University, Bratislava. Gondová 2, 81801 Bratislava 16. funkyfish@pobox.sk
} 
and $17^{\text {th }}$ centuries. Among numerous printings and manuscripts of sacred characters predominantly, also some relics of secular instrumental music were preserved from those times. Among them three printed lute tablature books, too [5] Two of these - Waisselius`s Tabulaturbuch from 1592 [10] and Besard's Thesaurus harmonicus from 1603 [11] have been preserved until today. About the last Phales's printing Lucullentum theatrum muscum from 1568 [1] we can learn from literature [1]. The occurrence of these pieces of art witnesses the presence of brilliant players among nobility or townsfolk of whom we can claim that they reached the same level as the European ones. We do not have much knowledge about the way of education of lute playing as well as of education of professional lute players in this area. We know that in Banská Bystrica Gerle's lute book from 1546 was used, which is a part - as Marta Hulková claims - of music collection of the library of Johann Dernschwam. The library is currently archived in Nationalbibliothek of Vienna (sig. Cod. 12652). In Levoča Besard's lute book from 1603 containing lute instructions was used [12].

The preserved lute books' repertoire of lute players active in the area of the former Hungary is dominated by Italian and German composers, but there are also some compositions of French and English authors. As Király says, for example the content of Waisselius's tablature is identical with the contents of richer Czech, Polish, Austrian and German collections [9]. In the repertoire of Bakfark, both Newsidlers and also Tinódi we could find some compositions containing characteristic features of music of various countries, influenced by folk elements of certain environment as well phantasies, preambles, intavulations and international dance compositions [9]. The professional lute players are supposed to have played international repertoire, but they certainly played some of their own compositions, too. The dance compositions formed the main part of European lute repertoire of those times. Lute became the means of their popularization in our territory. From the above mentioned (though fragmentary) facts we can conclude that lute music in the area of the contemporary Slovakia might have been present to a much greater extent than one would have expected.

\section{Jean Baptista Besard [13]}

He was born around 1567 in Jussey or Besancon, and died after 1617. He studied law and theology at a university in Dôle and graduated there in 1587 in civil and ecclestiastical law. From 1587 to 1592 (or 1596) he stayed in Rome where he probably studied medicine and learned to play the lute at Laurencini [13]. On $13^{\text {th }}$ May 1592 Besard was matriculated at a university in Heidlberg. No later than from March 1597 he was active in Koln where he tutored at least 20 students of lute. In summer or autumn 1597 he was not successful in applying for the position of a lute player in the court of the landgrave Moritz Hessen in Kassel. From October 1600 to March 1601 he worked as a lute teacher in Koln. In February 1602 in Besancon he married Péronne Jacquot. She came from an aristocratic family of lawyers. In 1603 in Koln Besard published - at his own expense - lute anthology Thesaurus hamon- icus. In 1604 in Koln he compiled the $5^{\text {th }}$ volume of Mercurii Gallobelgici, one of the most plentiful series of edition of historical and law documents. Besard's relations to Besancon were very close at that time. Thesaurus and Mercurii are dedicated to personalities from Franche - Comté. In October 1605 he had to go back to Besancon to arrange law and economic claims of his wife which resulted from their marriage settlement. During the following years Besard spent most of the time in Koln. In November 1613 he came back to Besancon again to receive his wife's father's patrimony after he had died the same year. Around 1617 Besard settled in Augsburg, the hometown of his friend Phillip Hainhofer. Thanks to Besard, encyclopaedia of diseases and medical procedures Antrum philosophicum, the collection for lute orchestra Novus partus [14] and school for luteplaying Isagoge in artem testudinarium [14] which he dedicated to his four Augsburg students were published here. Besard left Augsburg shortly after publishing Novus partus on $1^{\text {th }}$ September 1617 .

Tablatures from Besard's collection which were not attributed to other authors, may not have been written by Besard himself as he was considered to be more a publisher and an elaborator. His authorship of majority of works that are connected with his name is uncertain as well. Jean Baptista Besard was also the author of books and writings concerning music like De modo in testudine libellus [11] that is a part of Thesaurus $\mathrm{He}$ is the author of $A d$ artem which is a revised edition of De Modo.

Some other documents written by him are: Mercurio Gallobelgici from 1604, which is the collection of historical documents, Antrum philosophicum in quo pleraque arcana physica quae ad vulgariores humani corporis affectus currandos attinent, which is a large compendium of medical knowledge of that period.

\section{Thesaurus harmonicus}

The original of this precious document is a part of Levoča's collection of music and is in the depository of the Evangelical Church under the signature 5157, new signature is 7A. It is also available in the form of a microfilm at The Institution of Musical Science of Slovak Academy of Science (SAV) in Bratislava. The musical print Thesaurus harmonicus divini Laurencini Romani, Koln 1603, contains 405 compositions in French lute tablature in ten books, from which probably 46 works are Besard's, 4 preludes, 3 phantasies, 6 canciones gallicae, 9 passamez, pavana hispanica, bergamesca, 4 galiards, 14 allemandes, courant de guerre and 3 ballets.

Besard's lute music is not of extraordinary quality. Short preludes win the audiences over mostly with their improvisational quality while long passamezo - variations consist only of many mechanical cumulated reversed chords. Compositions are characterized by very difficult technique of play. Frequent and extreme change of positions, fast passages, nervous rhythm, unusual touch sequences as well as expressive disonancies show that Besard was a pupil of the great Italian lute virtuoso Laurencini. Thesaurus, European anthology of lute music which includes nearly complete 
sequencing of lute music, preludes, phantasies, intavulations of madrigals, psalms and chansons, songs accompanied by lute, dance forms like passamezo, galliard, allemand, courant, branl, contains apart from known pieces also compositions of unknown composers. Thesaurus was used by lute players from all Europe as a source of a new repertoire as well as a textbook and a manual. The repertoire collected by Besard in this work emphasizes lute encyclopaedic knowledge of that period. As the most appreciated lute player of his time he considers, apart from his teacher Laurencini, a Frenchman A. Francisque whose collection Trésor d'Orpheé is similar to Thesaurus [14]. A Norimberg editor of the large lute anthology Testudo Gallo-Germanica from 1615 G. L. Fuhrmann was in personal contact with Besard which is evidenced by Besard's vote of thanks and a high number of concordances between Fuhrmann's publications and Thesaurus. Another model for this collection are also publications of Piere Phalese [13].

In the introduction Besard deals with the typology and classification of various forms. In case of e.g. galliard, which Besard dedicated one whole book, he differentiates dance form with a periodical structure and stylized galliarde with variation forms. Thesaurus with 14 Besard's compositions in the $7^{\text {th }}$ book was the most important source for allemand at that time.

\section{Conclusion}

In the end we can conclude that musical life in Slovakia in the period of humanism - even if little later - tried to keep up with the development of trends in European secular music which is proved also by the existence of some precious documents of lute music of that period in this area. It is also recorded in primary and secondary sources. At the beginning of the $17^{\text {th }}$ century Jean Baptista Besard was considered the best expert at the technique of lute playing. Along with the stated historical facts Besard is presented as a well educated man in more fields which only confirms the ideal of a man of those times.

\section{References}

[1] ZAGIBA, F.: History of Slovak music since ancient music to age of reformation (in Slovak), Bratislava, 1943

[2] RYBARIČ, R.: History of Slovak musical culture (in Slovak), Opus, Bratislava, 1984, vol. I

[3] KAČIC, L.: Renaissance (in Slovak), In: History of Slovak music (ed. Elschek), ÚHV SAV, Bratislava, 1996, pp. 64-67.

[4] BURLAS, L., FIŠER, J., HOŘEJŠ, A.: Music in the area of Slovakia in XVII. century (in Slovak), SAV, Bratislava, 1954

[5] HULKOVÁ, M.: Concords and differences in Bardejov's a Levoča's collection of music (in Slovak), In: Slovak music XXV, 2-3/1999, Bratislava, pp. 150-189.

[6] ŠIŠKOVÁ, I.: The main rules of transcriptions of Levoča's lute tabulature (in Slovak), In: Music archives, Martin, 1981, pp. 387-404

[7] KIRÁLY, P.: Lute music in Hungary in $16^{\text {th }}$ and $17^{\text {th }}$ century (in Hungary), Balassi Kiado, Budapest, 1995

[8] MMG: Die Musik in Geschichte und Gegenvart - Personennteil, Kassel 1999-2000, vol. 1-5

[9] KALINAYOVÁ, et al: Music inventories and repertoire of polyphonic music of Slovakia in $16^{\text {th }}$ and $17^{\text {th }}$ century (in Slovak), Museum Musicum, Bratislava, 1994

[10] BROWN, HOWARD, MAYER: Instrumental Music printed before 1600, Oxford University Press, London, 1965

[11] BESARD, J. B.: Thesaurus Harmonicus, Köln, 1603, reprint, Minkoff, Geneve, 1975

[12] HULKOVÁ, M.: Music documents in library of Johann Dernschwam (in Slovak), In: Historical - Ethnological studies II., UMB, Banská Bystrica, 2001, pp. 91-102

[13] SUTTON, J.: Jean Baptista Besard, In: http://mambers01.chello.se/oljelund/newlute/besard.html, Jean Baptista Besard, In The New Grove, London, 1995, vol. II, pp. 656-657.

[14] RISM - Repertoir International Des Sources Musicales, (ed. Schlager K.), file prints, $16^{\text {th }}-17^{\text {th }}$ century, B $/ \mathrm{I} / 1$ München - Duisburg, 1960

[15] New Grove Dictionary of Music and Musicians (ed. S. Sadie), London 1965, vol. 11, pp. 234-235. 